ЩОДО ПИТАНЬ ПРОФІЛАКТИКИ СЕЧОКИСЛОГО ДІАТЕЗУ

В ІНДИЧАТ

С. Г. ВИШНЕВСЬКИЙ, асистенТ

М. І. ЦВІЛІХОВСЬКИЙ, доктор біологічних наук, професор

Національний університет біоресурсів і природокористування Украӥни

E-mail:esculat@bigmir.net

Анотація. Сечокислий діатез $є$ досить поширеним захворюванням незаразної етіології у птиці $i$ пов'язане з генетичними передумовами його виникнення, оскільки урикотелічні організми проходять внутрішньоутробний розвиток в яйці. Внаслідок ичого у крові птиці підвищується вміст сечової кислоти, а в органах і тканинах відкладаються ї̈ сечокислі солі. У сучасній ветеринарній медицині не існує чіткої схеми ранньої профілактики сечокислого діатезу в індиків. Вітамінні препарати та кормові добавки, які рекомендується застосовувати з метою профілактики порушень обміну речовин, не завжди дають позитивні результати. Це пов'язано з тим, що не враховується ряд факторів, таких як: напрямок продуктивності $i$ видові особливості птииі, етіологія $i$ патогенез захворювання, збалансованість раціону за поживними речовинами, біогеохімічна особливість регіону та інші. Встановлено, що за згодовування впродовж 1-го місяия індичатам, починаючи з 30-добового їх віку, із профілактичною метою препарату «Індикамін» у дозі 1 г/кг корму, покращується загальний стан птииі, залишаються стабільними морфологічні $і$ біохімічні показники крові та не відбувається накопичення в організмі індичат сечової кислоти, щь усуває ризики розвитку в них сечокислого діатезу.

Ключові слова: індичата, сечова кислота, морфологічні та біохімічні дослідження крові, профілактика сечокислого діатезу.

Актуальність. В умовах збереження високої інтенсивності яйценосності і приросту маси тіла сільськогосподарської птиці за промислових технологій вирощування не завжди вдається утримувати іï на раціонах 3 оптимальним рівнем протеїну, особливо тваринного походження [1]. Одним із найпоширеніших захворювань незаразної етіології, яке найчастіше діагностують у індиків за екстенсивної технології їх вирощування є сечокислий діатез. Захворювання може спостерігатися у 20-30 \% поголів'я індиків і воно характеризується порушенням обміну білків у їх організмі, внаслідок чого в 
крові птиці підвищується уміст сечової кислоти, а в органах і тканинах відкладаються її сечокислі солі [6-8].

Мета дослідження - вивчити клінічний прояв, гематологічні та біохімічні показники крові у хворих на сечокислий діатез індичат одномісячного віку за екстенсивної технології вирощування, а також розробити новий ветеринарний препарат Індикамін на основі лактатних сполук макро- i мікроелементів, адсорбенту та пребіотика Триман-П і показати його профілактичну ефективність за цієї патології в індичат.

Матеріали і методи досліджень. Нами був проведений науковогосподарський дослід на індичатах кросу Б’юті-8 із метою застосування препарату Індикамін для групової профілактики сечокислого діатезу.

Вік індичат на початку експерименту 30 діб. Термін експерименту 1 місяць. Індичата контрольної групи $(\mathrm{n}=100)$ утримувались на прийнятому в господарстві основному раціоні. Індичата дослідної групи $(n=100)$ отримували основний раціон, препарат Індикамін у дозі 1,0 г/кг корму. На початку та в кінці експерименту в індичат дослідних груп досліджували клінічний статус, морфологічні та біохімічні показники крові, визначали масу тіла.

Результати досліджень та їх обговорення. На початку досліду індичата контрольної та дослідної груп мали задовільний загальний стан, добре поїдали корм та реагували на зовнішні подразники, були клінічно здоровими.

В кінці досліду у 8 \% індичат контрольної групи була відмічена анемічність гребінця і коралів, у 10 \% - випадіння пір'я в ділянці спини і хвоста. Середня маса тіла індичат у віці 90 діб становила 3560 г, початок яйценосності наставав у них у віці 210 діб, а виводимість індичат 3 яєць становила $80,7 \%$.

Під час дослідження морфологічних показників крові $(\mathrm{n}=10)$ на початку досліду значних розбіжностей між індичатами контрольної та дослідної груп не відмічалося.

В кінці досліду у крові індичат дослідної групи встановлено в 1,27 рази достовірну більшу кількість еритроцитів порівняно з цим показником у індичат 
контрольної групи [2-3]. Результати досліджень вказують на покращення процесів еритроцитопоезу в індичат дослідної групи порівняно 3 індичатами контрольної групи. Це може бути обумовлено впливом складових компонентів препарату Індикамін на процеси еритроцитопоезу в організмі індичат, а саме Феруму лактату, Купруму лактату та Кобальту лактату (табл. 1).

1. Морфологічні показники крові індичат на початку та в кінці досліду, $\mathrm{M} \pm \mathbf{m}, \mathbf{n}=\mathbf{1 0}$

\begin{tabular}{|c|c|c|c|c|c|c|}
\hline & \multirow{2}{*}{\multicolumn{2}{|c|}{ Показники }} & \multicolumn{2}{|c|}{$\begin{array}{c}\text { Контрольна група, } \\
\text { основний раціон }\end{array}$} & \multicolumn{2}{|c|}{$\begin{array}{c}\text { Дослідна група, } \\
\text { основний раціон+Індикамін }\end{array}$} \\
\hline & & & $\begin{array}{l}\text { Початок } \\
\text { досліду }\end{array}$ & $\begin{array}{l}\text { Кінець } \\
\text { досліду }\end{array}$ & $\begin{array}{l}\text { Початок } \\
\text { досліду }\end{array}$ & $\begin{array}{l}\text { Кінець } \\
\text { досліду }\end{array}$ \\
\hline \multicolumn{3}{|c|}{ Еритроцити, Т/л } & $3,1 \pm 0,21$ & $3,0 \pm 0,12$ & $3,1 \pm 0,14$ & $3,8 \pm 0,05^{*}$ \\
\hline \multicolumn{3}{|c|}{ Гемоглобін, г/л } & $82,10 \pm 2,15$ & $75,30 \pm 1,05^{*}$ & $83,2 \pm 1,43$ & $90,2 \pm 1,22^{*}$ \\
\hline \multicolumn{3}{|c|}{ Тромбоцити, Г/л } & $40,5 \pm 2,55$ & $41,4 \pm 3,24$ & $41,5 \pm 1,25$ & $42,3 \pm 2,01$ \\
\hline \multicolumn{3}{|c|}{ Лейкоцити, Г/л } & $35,6 \pm 1,46$ & $38,2 \pm 1,32$ & $36,3 \pm 1,63$ & $36,4 \pm 1,18$ \\
\hline \multicolumn{3}{|c|}{ Базофіли } & $1,0 \pm 0,01$ & $1,0 \pm 0,04$ & $1,0 \pm 0,15$ & $1,0 \pm 0,10$ \\
\hline \multirow{7}{*}{ 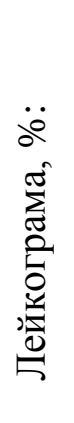 } & \multicolumn{2}{|c|}{ Еозинофіли } & $0,8 \pm 0,02$ & $1,2 \pm 0,22$ & $0,7 \pm 0,03$ & $0,5 \pm 0,06$ \\
\hline & \multirow{4}{*}{ 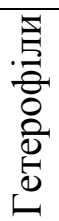 } & $\mathrm{M}$ & - & - & - & - \\
\hline & & Ю & $2,06 \pm 0,21$ & $2,0 \pm 0,55$ & $1,40 \pm 0,27$ & $1,9 \pm 0,49$ \\
\hline & & $\Pi$ & $16,60 \pm 1,47$ & $18,20 \pm 1,32$ & $17,3 \pm 1,43$ & $15,60 \pm 1,27$ \\
\hline & & $\mathrm{C}$ & $21,0 \pm 1,53$ & $23,4 \pm 1,45$ & $21,5 \pm 1,35$ & $18,1 \pm 1,22$ \\
\hline & \multicolumn{2}{|c|}{ Лімфоцити } & $55,44 \pm 3,04$ & $48,2 \pm 3,17 *$ & $54,30 \pm 2,48$ & $59,7 \pm 2,62 *$ \\
\hline & \multicolumn{2}{|c|}{ Моноцити } & $3,1 \pm 0,12$ & $6,0 \pm 0,03$ & $3,8 \pm 0,25$ & $3,2 \pm 0,15$ \\
\hline
\end{tabular}

Примітки: *p $\leq 0,05$ порівняно з контрольною групою

В кінці досліду у крові індичат дослідної групи встановлено в 1,20 рази достовірно вищий вміст гемоглобіну, порівняно з цим показником у індичат контрольної групи, що пов'язано із покращенням процесів гемопоезу в організмі індичат під впливом компонентів препарату Індикамін [4-5].

Про підвищення рівня природної резистентності організму індичат дослідної групи порівняно з індичатами контрольної групи свідчить показник кількості лімфоцитів у їх крові. Так, у кінці досліду було встановлено, що кількість лімфоцитів у крові індичат дослідної групи в 1,24 рази достовірно більша порівняно із цим показником у індичат контрольної групи. 
Одержані нами дані вказують на більш інтенсивний метаболізм білків у організмі індичат дослідної групи, порівняно з індичатами контрольної групи. Так, уміст загального білка у плазмі крові індичат дослідної групи в кінці експерименту був у 1,21 рази достовірно нижчим порівняно з цим показником у індичат контрольної групи (табл. 2).

2. Біохімічні показники крові індичат на початку та в кінці досліду, $\mathrm{M} \pm \mathbf{m}, \mathbf{n}=\mathbf{1 0}$

\begin{tabular}{|c|c|c|c|c|}
\hline \multirow{2}{*}{ Показники } & \multicolumn{2}{|c|}{$\begin{array}{l}\text { Контрольна група, } \\
\text { основний раціон }\end{array}$} & \multicolumn{2}{|c|}{$\begin{array}{c}\text { Дослідна група, } \\
\text { основний раціон+Індикамін }\end{array}$} \\
\hline & $\begin{array}{c}\text { Початок } \\
\text { досліду }\end{array}$ & $\begin{array}{l}\text { Кінець } \\
\text { досліду }\end{array}$ & $\begin{array}{c}\text { Початок } \\
\text { досліду }\end{array}$ & $\begin{array}{l}\text { Кінець } \\
\text { досліду }\end{array}$ \\
\hline Загальний білок, г/л & $45,35 \pm 1,31$ & $56,20 \pm 1,25^{*}$ & $44,10 \pm 2,38$ & $46,33 \pm 1,16$ \\
\hline Альбуміни, г/л & $14,15 \pm 1,01$ & $20,38 \pm 1,50 *$ & $12,64 \pm 1,02$ & $14,04 \pm 1,12$ \\
\hline Глобуліни, г/л & $31,20 \pm 1,21$ & $35,82 \pm 1,23$ & $31,46 \pm 1,12$ & $32,29 \pm 1,10^{*}$ \\
\hline Білковий коеф., од. & 0,45 & 0,56 & 0,40 & 0,43 \\
\hline АлАТ, ммоль/(год•л) & $0,53 \pm 0,01$ & $0,74 \pm 0,09 *$ & $0,58 \pm 0,05$ & $0,49 \pm 0,05 \downarrow$ \\
\hline АсАТ, ммоль/(год•л) & $1,20 \pm 0,14$ & $1,85 \pm 0,14^{*}$ & $1,18 \pm 0,02$ & $1,27 \pm 0,01 \diamond$ \\
\hline ЛФ, мкмоль/(год•мл) & $11,00 \pm 1,16$ & $11,28 \pm 1,23$ & $10,05 \pm 1,53$ & $11,8+1,45$ \\
\hline Кальцій заг., ммоль/л & $2,52 \pm 0,10$ & $2,21 \pm 0,12^{*}$ & $2,70 \pm 0,03$ & $3,11+0,01 * \diamond$ \\
\hline Фосфор неорг., ммоль/л & $1,65 \pm 0,04$ & $1,43+0,08^{*}$ & $1,68 \pm 0,04$ & $1,72 \pm 0,05$ \\
\hline $\mathrm{Ca} / \mathrm{P}$, од & 1,53 & 1,55 & 1,61 & 1,81 \\
\hline Сечова кислота, ммоль/л & $0,28 \pm 0,01$ & $0,33 \pm 0,02$ & $0,27 \pm 0,05$ & $0,21 \pm 0,01 *$ \\
\hline
\end{tabular}

Примітки: $* p \leq 0,05$ порівняно з контрольною групою

Активність АлАТ і АсАТ у плазмі крові індичат контрольної групи в кінці експерименту була достовірно вищою відповідно у 1,51 та 1,46 рази порівняно з активністю цих ферментів у плазмі крові індичат дослідної групи. Це може свідчити про появу дегенеративних змін у печінці індичат контрольної групи.

У плазмі крові індичат дослідної групи впродовж одномісячного застосування їм препарату Індикамін в 1,45 рази достовірно підвищився вміст Кальцію загального, тоді як у плазмі крові індичат контрольної групи за цей же період вміст Кальцію загального, а також Фосфору неорганічного, навпаки достовірно знизився відповідно у 1,14 та 1,15 рази порівняно 3 початком досліду. Водночас показник Кальціє-Фосфорного співвідношення у плазмі крові індичат дослідної групи був значно вищим і становив 1,81, а в індичат 
контрольної групи - 1,55. Одержані нами дані вказують на покращення засвоюваності та депонування в організмі індичат Кальцію, який входить до складу препарату Індикамін.

В кінці експерименту у плазмі крові індичат дослідної групи встановлено в 1,45 рази достовірно нижчу концентрацію сечової кислоти порівняно 3 індичатами контрольної групи (рис. 1).

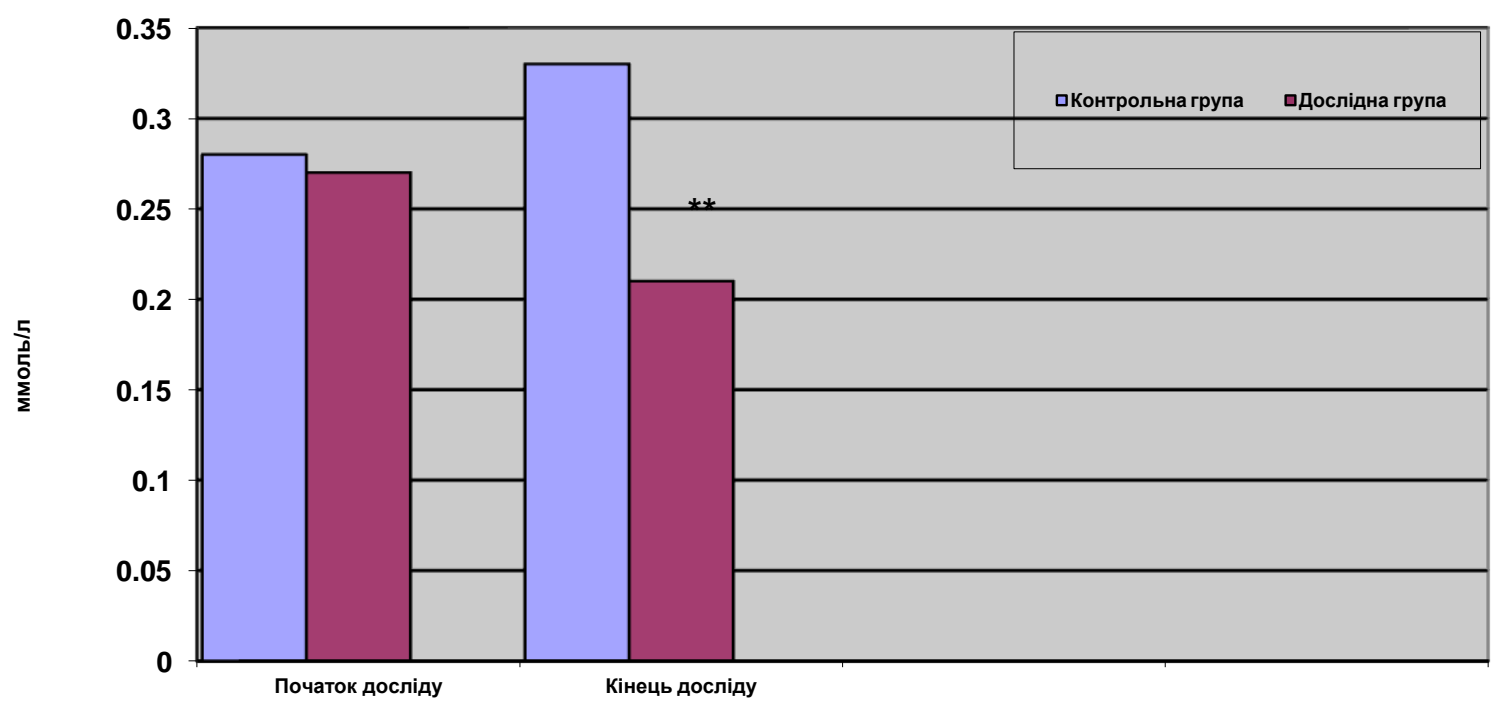

Рис. 1. Уміст сечової кислоти у плазмі крові індичат на початку та по завершенню проведення заходів із попередження виникнення сечокислого діатезу, $\mathrm{M} \pm \mathbf{m}, \mathbf{n}=\mathbf{1 0}$

Примітки: **p $\leq 0,01$ порівняно з контрольною групою

Зниження в плазмі крові індичат вмісту сечової кислоти може бути пов'язане із покращенням процесів фільтрації та виведення сечі через нирки, оскільки компоненти препарату Індикамін мають вираженні адсорбуючі властивості та покращують роботу нирок [3-4]. Натомість пребіотик Триман-П, який входить до складу препарату Індикамін сприяє покращенню процесів травлення та всмоктування поживних речовин у шлунково-кишковому тракті птиці та запобігає виникненню і розвитку в них порушень травлення.

Висновки. Таким чином, отримані нами результати показують, що за застосування упродовж 1-го місяця індичатам, починаючи із 30-добового їх віку із профілактичною метою препарату Індикамін у дозі 1 г/кг корму, покращується загальний стан птиці, залишаються стабільними морфологічні і 
біохімічні показники крові та не відбувається накопичення в організмі індичат сечової кислоти, що усуває ризики розвитку в них сечокислого діатезу.

Перспективи подальших досліджень. Подальші дослідження необхідно спрямувати на дослідження патогенезу сечокислого діатезу в птиці та нових методів діагностики даної патології в умовах господарства.

\section{Список літератури}

1. Богач М. В. Індики та їх хвороби / М. В. Богач. - Монографія. Одеса: Астропринт, 2010. - 241 с.

2. Вишневський С. Г. Порушення обміну сечової кислоти в організмі індиків кросу Б’юті-8 при сечокислому діатезі / С. Г. Вишневський, О. В. Поліщук. - Науковий вісник НАУ. - 2008. - № 127. - С. 68-71.

3. Вишневський С. Г. Ефективна схема лікування індичат хворих на сечокислий діатез / С. Г. Вишневський // Вісник Житомирського національного агроекологічного університету. - 2012. - Том 3. - № 1(32), Ч.1. - С. 291-300.

4. Вишневський С. Г., Дульнєв П. Г., Береза В. І., Цвіліховський М. І. Патент України на винахід 83607, МПК А61К 31/33. Ветеринарний препарат для профілактики та лікування сечокислого діатезу у індиків; заявник i патентовласник Дульнєв П. Г.; заявл. 17.10.2007; опубл. 25.07.2008; Бюл. № 14.

5. Вишневський С. Г., Дульнєв П. Г., Береза В. І., Цвіліховський М. І. Патент України на винахід 83952, МПК А61К 31/44. Застосування аква-Nоксид-2диметилпіридинмарганець(II)хлориду; заявник і патентовласник Дульнєв П. Г.; заявл. 03.05.2007; опубл. 26.08.2008; Бюл. № 16.

6. Имангулов Ш. А. Мочекислый диатез•Подагра•Мочекаменная болезнь / Ш.А. Имангулов, Т.Т. Папазян, А.Ш. Кавтарашвили.- Москва: Сергиев Посад, 2001.-39 с.

7. Alan M. In primary gout, the hyperuricemia is due to an overproduction of uric acid / M. Alan. - Laboratory medicine: avian and exotic pets. - 1999. -P. 215.

8. Banday M.T. Avian Gout: Causes Treatment and Prevention / M.T. Banday, Mukesh Bhakt, Sheikh Adil Hamid. - Srinagar, Kashmir, India. - 2009. №5. - P. 26.

\section{References}

1. Bogach, N. V. (2010). Indyky ta yikh khvoroby [Turkey and their illnesses]. Astroprint, 241.

2. Vishnevskyi, S. G., Polyschuk, A. V. (2008). Porushennya obminu sechovoyi kysloty $\mathrm{v}$ orhanizmi indykiv krosu B"yuti-8 pry sechokyslomu diatezi [Violation of urinary acid metabolism in the turkeys of the But- 8 cross-breed with uric acid diathesis]. Scientific bulletin of NAU, 127, 68-71.

3. Vishnevskyi, S. G. (2012). Efektyvna skhema likuvannya indychat khvorykh na sechokyslyy diatez [An effective treatment regimen for turkeys in 
patients with uric acid diathesis]. Bulletin of Zhytomyr National Agroecological University, 3 (32), 291-300.

4. Vishnevskyi, S. G., Dulnev P. G., Bereza V. I., Tsvilichovskyi M. I. Veterinary drug for the prevention and treatment of uric acid diathesis in turkeys. Patent of Ukraine for invention. A61K 31/33. № 83607; declared 17.10.2007; published 25.07.2008, № 14 .

5. Vishnevskyi, S. G., Dulnev P. G., Bereza V. I., Tsvilichovskyi M. I. Application of aqua-N-oxide-2-dimethylpyridine-manganese (II) chloride. Patent of Ukraine for invention. A61K 31/44. № 83952; declared 03.05.2007; published 26.08.2008, № 16 .

6. Imangulov, Sh. A., Papazyan, T. T., Kavtarashvili, A. Sh. (2001). Mochekislyy diatez $\bullet$ Podagra $\bullet$ Mochekamennaya bolezn [Urine acid diathesis • Gout • Urolithiasis]. Sergiev Posad, 39.

7. Alan M. (1999). In primary gout, the hyperuricemia is due to an overproduction of uric acid. Laboratory medicine: avian and exotic pets, 215.

8. Banday M.T., Mukesh Bhakt, Sheikh Adil Hamid (2009). Avian Gout: Causes Treatment and Prevention, Srinagar, Kashmir, India, 5, 26.

\section{ПО ВОПРОСАМ ПРОФИЛАКТИКИ МОЧЕКИСЛОГО ДИАТЕЗА У ИНДЮШАТ \\ С. Г. Вишневский, Н. И. Цвилиховский}

Аннотация. Мочекислый диатез является довольно распространенным заболеванием незаразной этиологии у птищы и связано с генетическими предпосылками его возникновения, поскольку урикотелические организмы проходят внутриутробное развитие в яйце. В результате в крови птиць повынается содержание мочевой кислоты, а в органах и тканях откладываются ее мочекислье соли. В современной ветеринарной медицине не существует четкой схемы ранней профилактики мочекислого диатеза в индюков. Витаминные препараты и кормовые добавки, которые рекомендуется применять с иелью профилактики нарушений обмена веществ, не всегда дают положительные результаты. Это связано с тем, что не учитывается ряд факторов, таких как: направление производительности и видовые особенности птиџы, этиология и патогенез заболевания, сбалансированность рациона по питательным веществам, биогеохимическая особенность региона и другие. Установлено, что при скармливаемый в течение 1-го месячуа индюшатам, начиная с 30-суточного их возраста, с профилактической целью препарата «Индикамин» в дозе 1 г/кг корма, улучшается общее состояние птищы, остаются стабильными морфологические и биохимические показатели крови и не происходит накопления в организме индюшат мочевой кислоты, устраняет риски развития у них мочекислого диатеза.

Ключевые слова: индюшата, мочевая кислота, морфологические и биохимические исследования крови, профилактика мочекислого диатеза 


\title{
TO QUESTIONNAIRE OF PREVENTION OF URIC ACID DIATHESIS OF TURKEY
}

\section{S. G. Vishnevskyi, M. I. Tsvilichovskyi}

\begin{abstract}
Urea diathesis is a fairly widespread disease of non-contagious etiology in birds and is associated with genetic preconditions for its occurrence, since the erythrocyte organisms undergo fetal development in an egg. As a result, in the blood of the bird, the uric acid content increases, and in the organs and tissues its molic acid salts are deposited. In modern veterinary medicine there is no clear scheme for early prevention of diuretic urea in turkey. Vitamin preparations and feed supplements that are recommended for preventing metabolic disorders do not always produce positive results. This is due to the fact that several factors are not taken into account, such as: the direction of productivity and species characteristics of the bird, the etiology and pathogenesis of the disease, the balance of the diet on nutrients, the biogeochemical feature of the region, and others. Application of turkey the age of 1 month, within 30 days of the drug «Indikamin» at a dose of $1.0 \mathrm{~g} / \mathrm{kg}$ of feed prevents the occurrence of uric acid diathesis and is an effective method of prevention of this pathology.
\end{abstract}

Key words: turkey, uric acid, morphological and biochemical studies of blood, prevention of uric acid diathesis 